\title{
SERIA HORA DE PUBLICAR MAIS EM INGLÊS?
}

Há nitidamente duas rotas de publicação científica no Brasil, assim como em outros países emergentes: uma voltada para os periódicos internacionais e a outra para os nacionais. ${ }^{1}$ Dependendo da natureza e do nível de qualidade alcançado em cada área científica no país, há uma tendência para tomar uma ou outra rota. Esta dicotomia não é encontrada em países desenvolvidos onde os periódicos nacionais tendem a ter um caráter internacional.

No Brasil, a linha divisória é muito nítida em muitas áreas. A química, no entanto, alcançou um significativo recobrimento entre as duas rotas. Os cientistas mais destacados, embora publicando intensamente em expressivos periódicos internacionais, publicam, com significativa frequência, em periódicos nacionais. Dentre estes se destacam Química Nova (QN) e Journal of the Brazilian Chemical Society, ambos publicados pela Sociedade Brasileira de Química.

Como exercício para iniciar este ensaio editorial, considerei trinta e dois cientistas brasileiros destacados na área de química, assim considerados pelos pares e por dados cienciométricos. Constatei que, em média, 5\% de seus artigos são publicados na QN. Isto apesar de alcançarem visibilidade três vezes menor de seus artigos no periódico nacional em comparação aos periódicos internacionais, a julgar pela média de citações por artigo.

É provável e compreensível que os artigos mais promissores destes cientistas sejam reservados para submissão em periódicos internacionais. De qualquer forma, algo os estimula a publicar em um periódico nacional, bem além do que ocorre em outras áreas de ciências naturais no Brasil em que a busca por publicações internacionais também é forte. Ademais, chama a atenção que $83 \%$ desses artigos sejam em português, levando em conta que estes cientistas se sentem bem a vontade para redigir artigos em inglês.

Não creio que esses artigos foram originalmente encaminhados a periódicos internacionais e após denegação encaminhados para QN como tábua de salvação. Até pelo próprio fato de serem na sua grande maioria em português.

Creio que a origem desta tendência está na proposta original de QN. O primeiro número do periódico foi lançado em janeiro de 1978. Cautelosamente, seu criador e editor, Eduardo Peixoto, não mencionou em seus primeiros editoriais a que veio. Apenas no último número de 1979, quando se assegurou de que o periódico sobreviveria, é que se manifestou sobre ele: um veículo para divulgar e fortalecer a química brasileira e usar exclusivamente o português. Julgava que este idioma destacar-se-ia "como o próximo idioma a impor-se no cenário científico das nações". ${ }^{2}$ Nesta época o português era a $15^{\text {a }}$ língua científica, hoje é a $6^{\text {a }}$. Porém, o uso de inglês em ciência neste período passou de $87 \%$ para $97 \%$. Desta forma, embora a expectativa de Peixoto de levar o idioma português para tal píncaro fosse um tanto fantasiosa, o uso exclusivo da língua materna na QN foi, naquele momento, fundamental para as metas da revista: divulgar e fortalecer a interação entre os químicos brasileiros. Mais ainda, acredito que esta iniciativa permitiu o acompanhamento do progresso da química com o desenvolvimento pari passu do vernáculo científico nacional da área, algo fundamental para o ensino de ciências. ${ }^{3}$

Certamente, a insistência da QN com o idioma nacional não é mais tão prevalecente, embora o inglês só tenha alcançado $30 \%$ dos textos publicados nestes últimos 3 anos. Por outro lado, houve um aumento significativo no número de artigos plenos. A impressão que se tem é que a revista continua num ponto de indecisão quanto aos rumos a tomar, talvez ainda influenciada pelos propósitos de sua origem. Num recente editorial ${ }^{4}$ fala-se dos progressos alcançados por QN, que são significativos. Comenta-se sobre os excelentes índices alcançados nas bases internacionais, considerando-se que os artigos são escritos majoritariamente em português. Tenho a mesma impressão. Até porque em um levantamento que fiz quanto aos artigos publicados, entre 2008-2012 as publicações da QN em português alcançaram 1490 e as publicações em inglês 392 (Web of Science). Se formos mirar para citações de artigos de autores estrangeiros aos artigos QN em português encontraremos 0,255 citações por artigo. Para artigos em inglês este número é de 0,923 citações por artigo. A lição é: os autores estrangeiros estão esperando para ler os artigos de QN em inglês. Talvez seja hora de estimular publicações em inglês.

Rogerio Meneghini

Coordenador Científico do Programa SciELO de periódicos científicos

\section{REFERÊNCIAS}

1. Meneghini, R.; Emerging journals: The benefits of and challenges for publishing scientific journals in and by emerging countries; Embo reports 2012, 13,106.

2. Peixoto E. M.; Equilíbrio, Editorial; Quim Nova 1979, 2,187.

3. Meneghini, R.: Packer, A. L.; Is there science beyond English? Initiatives to increase the quality and visibility of non-English publications might help to break down language barriers in scientific communication; Embo reports 2007, 8, 1.

4. Córdoba de Torresi, S. I.; Pardini, V. L.; Ferreira, V. F.; Editorial; O que esperamos das revistas da SBQ; Quim. Nova 2012, 35, 233. 